\title{
GIS modelling of bathymetric data in the construction of port terminals - An example of Vlaška channel in the Port of Ploče, Croatia
}

\author{
Ante Šiljeg(1), Branko Cavrić( ${ }^{(2)}$, Ivan Marić( $(1)$, Mirko Barada(3) \\ (1) Department of Geography, University of Zadar, Zadar, CROATIA \\ (2) Department of Architecture and Planning, University of Botswana, Gaborone, BOTSWANA \\ e-mail: cavricb@mopipi.ub.bw \\ (3) Centre for Karst and Coastal Research, University of Zadar, Zadar, CROATIA
}

\section{SUMMARY}

In the era of diversification of cargo freight facilities, application of advanced geo-modelling and geo-design tools is an imperative. Particularly, in the case of the new construction or redevelopments of large port terminals, its infrastructure and facilities. The main objective of this paper is to demonstrate the importance of bathymetric survey as one of the contemporary tools utilised in the pre-construction phase of port terminals. Contemporary bathymetry provides complex digital modelling and determines the depth, morphology and sedimentology of the river, lake, dam or sea beds. When planning, designing and constructing port terminals, bathymetric surveys are the primary prerequisite, before any physical intervention or material excavation. In order to generate a precise digital model of the sea-bed morphology in its initial and final stage, and calculate the quantity of the excavated material (in $\mathrm{m}^{3}$ ), our research team used geo-statistic and deterministic interpolation models. Particular emphasis was placed on the Newton-Cotes model affecting the output result (excavated material volume).

KEY WORDS: Port of Ploče, bathymetry, 3-D modelling, interpolation methods (IM), sea-bed, Vlaška channel.

\section{INTRODUCTION}

Sea ports are an indispensable part of the maritime natural and built environments. They are developing very fast and accelerate transportation systems lithoralization processes and the development and diversification of economic activities. The complexity of sea port terminals, technological advancements, and steady traffic growth, require incremental improvements of port capacities, in order to meet development trends $[5,9,16]$. The essential element for any 
port development is the optimal number and types of freight modes, with specific technical and technological characteristics. This results in the importance of planning the technical equipment of the port and its transhipment capacities [9].

The maritime trade is in constant global expansion. In order to meet increased demands from technical, managerial and customer points of view, it needs constant adaptation. This entails more attention to port specialization, the construction of new terminals, and strengthening of intermodal traffic through the development of their transport network to service hinterlands and remote areas [16].

The construction of new port terminals requires the implementation of a wide spectrum of different spatial interventions and activities. Some of these activities are: geodetic and bathymetric surveys, geophysical bedrock modelling, geotechnical sea-bed (sea-floor) modelling, climatological studies, seismic reports, definition of risk types and models of prevention, environmental impact assessment, wave disturbance predictions, determination of spatial requirements, development of protection measures (breakwater and slope protection), and many more $[4,22,26]$.

Furthermore, special emphasis was placed on carrying out the process of digital modelling of the sea-floor topography, which sought to determine the importance and influence of userdefined parameters on output results. User-defined parameters are the variables in the process of digital relief model that are set by the user, and have an impact on the output result. These parameters include: selecting data collection methodology, interpolation methods, decision on spatial resolution and spatial analysis algorithms.

The main two goals of this study were: (1) to point out the importance of bathymetry, and (2) to describe the overall process of digital modelling of sea-bed topography in the construction of a new port terminal.

The basic objectives of the study spawned further to include:

(a) to determine the most appropriate interpolation methods for creating raster models;

(b) to determine the most appropriate spatial resolutions for the created models;

(c) to determine the total volume between the initial (zero) and final stages of excavation.

\section{METHODS}

Various methods, techniques and procedures have been applied and integrated in order to obtain better quality outcomes. Deterministic and geostatistical interpolation methods, the methods of spatial (horizontal) resolution selection, digital relief analysis (volume calculation) and different visualization techniques, were concurrently used.

The research process was carried out in three phases. The first phase included literature review on sea port terminals, their construction processes and the importance of bathymetry in these operations. This stage has given a new insight into the importance of selecting appropriate user-defined parameters. This is particularly, so when designing digital models of sea-floor depth, which are important for the sea charts creation and calculation of excavated material volumes. At the end of this phase the sea-bed depth data in the initial (zero) and final stage were generated.

In the second phase, the sea-bed depth data in the initial (zero) and final stage were scrutinised by cross-validation method, which entailed the leave one technique and the eight 
statistical parameters. The most appropriate methods of interpolation were applied to calculate the volumes of excavated material.

The third and final phase of the research included calculation of the volume of excavated material using three Newton-Cotes formulae.

With regard to the numerous visuals presented in this research, the most suitable pixel size for the display of digital sea-floor depth graphical models was selected. This was done in order to achieve the highest possible accuracy of the under-water terrain model [36].

\section{STUDY AREA}

\subsection{LOCATION, LINKAGES AND SITE CHARACTERISTICS}

The Port of Ploče is the newest amongst all of the 409 Croatian ports, and the second most important national cargo port, located in the Dubrovnik-Neretva region [2, 23, 27] (Figure 1). The port was constructed during WWII. Its rapid development started in the 1970s, and is still ongoing (Figure 2). It stands as the main port for the southern part of the Adriatic coast. The port has a favourable geographical and strategic location, occupying the natural bay, $3 \mathrm{~km}$ northeast of the mouth of the Neretva river (Figure 1), protected from the south and southwest, by Pelješac peninsula, which acts as a natural offshore barrier [8,23].

Due to the proximity to the Neretva River Valley, the port has a natural access to the sea from the continental parts of Croatia, Bosnia and Herzegovina, Serbia, Montenegro, as well as the countries of Central and Eastern Europe [8]. Currently, the port has eight terminals and is categorized as a universal port.

The total annual transhipment capacity of Ploče is estimated at 4.8 - 5 million tonnes of bulk and general cargo [27], and the total storage capacity of liquid cargo of 600000.00 tonne. Container traffic capacity stays at 60000.00 TEU (twenty foot equivalent unit) per year [23]. The sea-bed depth of the terminal is about $13.8 \mathrm{~m}$ [24].

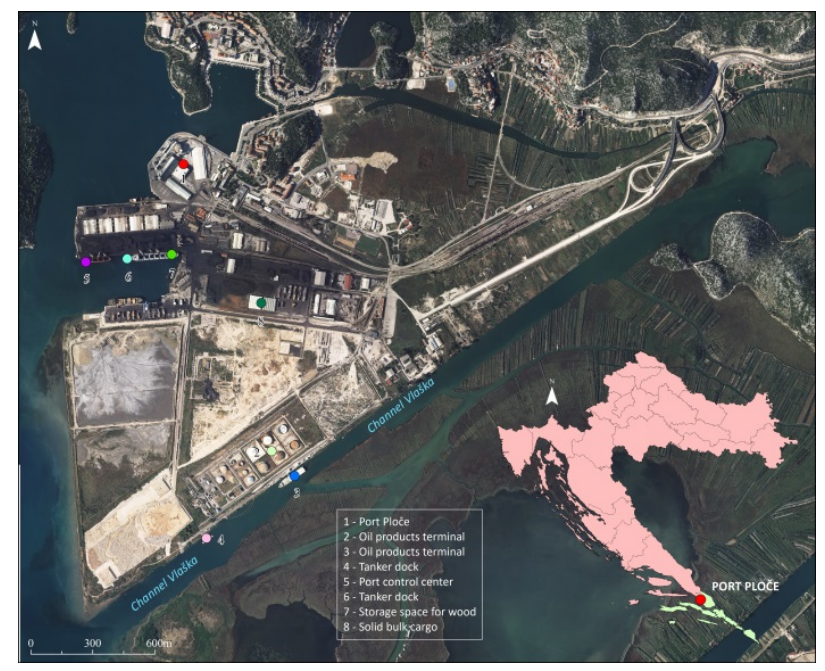

Fig. 1 Geographical location of The Port of Ploče

With the revitalization of the Corridor Vc (Ploče - Sarajevo - Osijek - Budapest), the port is identified as the "gate" to the branch of the Pan-European V Corridor $[3,28]$. This gives a large 
gravitational area, inclusive of the north-eastern Croatia, Bosnia and Herzegovina, part of Serbia, Montenegro, Austria, Hungary, the Czech Republic, Poland, Slovakia and Romania [8], and in fact represents the geographic link between the Baltic and the Adriatic Seas [23].

This strategic linkage is envisioned to be realised through the EU project "Integration of Trade and Transport". It will focus on the new construction and renewal of roads, local railway improvements, development of energy infrastructure, and expansion of port facilities [27].

The port covers a total of 230 hectares of land, sub-divided into twelve development zones: (i) bulk cargo - $9.35 \mathrm{ha}$; (ii) general and loose cargo - $11.42 \mathrm{ha}$; (iii) storage area for wood - 8.64 ha; (iv) liquid loads - $17.68 \mathrm{ha}$; (v) cooling facilities - $0.20 \mathrm{ha}$; (vi) special cargo - $20.00 \mathrm{ha}$; (vii) maintenance and service - $2.24 \mathrm{ha}$; (viii) passenger terminal - $1.50 \mathrm{ha}$; (ix) administrative building - $1.44 \mathrm{ha}$; (x) garages for equipment and vehicles - $2.96 \mathrm{ha}$; (xi) unused area - $7.29 \mathrm{ha}$; and (xii) future expansion zone - $147.58 \mathrm{ha}$ [25].

The bulk cargo terminal of the port of Ploče is occupied by the following areas: a) access to the Vlaška channel and the entrance channel where excavation is required to achieve adequate depth; b) Zone 1: surface of the planned terminal on the existing mainland area, and Channel Vlaška c) Zone 2: Area intended for the construction of the dock, storage area along the dock and new terminal expansion workspaces d) Zone 3: Ploče Harbor land area of 277,455 $\mathrm{m}^{2}$ provided for disposal of excavation material e) Zone 4: Sea port of Ploče is for disposal of excavated material of $115.200 \mathrm{~m}^{2}$ with a maximum depth of 4.80 to 5.90 meters [11].
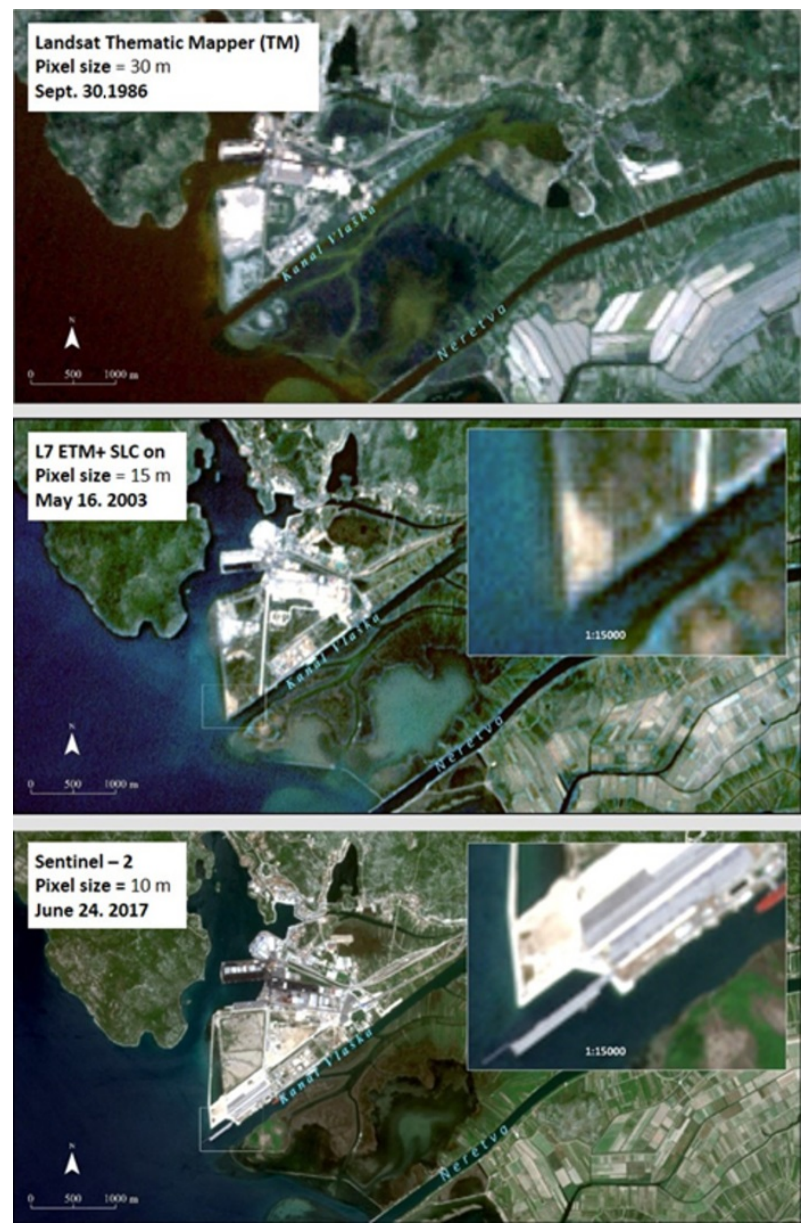

Fig. 2 The port of Ploče on satellite images in 1986, 2003 and 2017 (Source: [10]) 


\section{BATHYMETRY}

\subsection{DEFINITIONS}

Bathymetric survey is the process of studying and measuring the configuration of the bed (bottom) of the ocean, sea, lake, river and other forms of water bodies on earth [29], in order to obtain accurate data that will serve as a template for the creation of nautical charts in order to increase navigation safety [12].

As a scientific discipline, bathymetry belongs to remote sensing, because it determines the features of a particular spatial object without direct contact [6]. In its simplest version bathymetry assists in determining the depth of the sea-floor in relation to the sea level [6], using remotely recorded underwater depth data with $x, y$ (horizontal positions) and $z$ coordinates (depth).

Bathymetry information is important for the management and protection of coastal areas, pollution control, resource exploitation, national data infrastructure and related tourism activities that may include engineering works under water [19], quantitification of excavated material, water volume calculation, mapping of Benthic habitats [15], and finally construction and maintenance of ports, docks and terminals (Figure 3) [12].

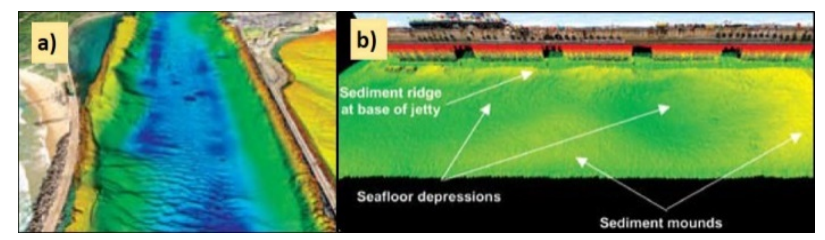

Fig. 3 a) 3D model depth of entry into the port

b) Perspective view of the sediment along the coastal wall [32a]

\subsection{BATHYMETRIC SURVEY METHODS AND TECHNIQUES}

The required precision of the bathymetric measurement can be in centimetres, meters or kilometres [6], depending on the scale and complexity of the project. For example, commercial projects require the highest level of accuracy, followed by situational projects with a middle level of accuracy and general knowledge projects with the lowest level of accuracy [34]. The type of project, the purpose of the measurement, and the spatial scope of the research, determine the type of technology (methods, techniques) to be used. The type of technology directly affects the density of collected samples (depth data), spatial resolution of the 3-D Benthic model of the study area and operational water depth (Figure 4). 


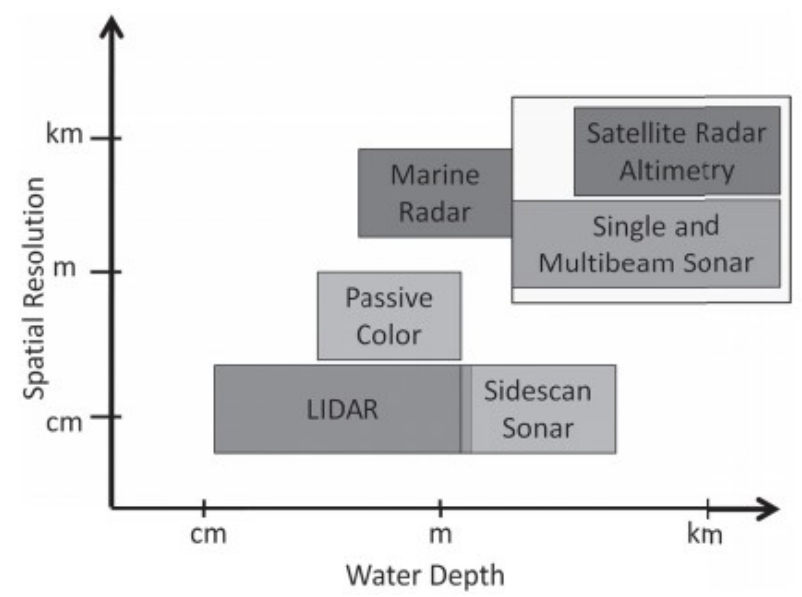

Fig. 4 Choice of technology vs. spatial resolution (Source: [6])

The accelerated technology developments over the last few decades have caused strong conceptual changes in bathymetric surveys. This began in the middle of the $20^{\text {th }}$ century, with the appearance of the single and multibeam echo sounders, a laser system aimed at collecting extremely high density data that allow representation of the underwater relief surface that is almost true to reality and satellite altimetry [35]. Today, the technology directs air beams to the earth's surface, and measures the strength and duration of the path of the emitted and reflected signals [6]. Considering their performance at different water depths the practice showed that depths up to $60 \mathrm{~m}$ have been measured with LIDAR systems, marine radar is accurate down to 40-50 $\mathrm{m}$ water depth, passive color in the clear waters down to $30 \mathrm{~m}$. Multibeam echo sounder EM $3002 \mathrm{D}$ used in this research goes up to $200 \mathrm{~m}$, while single-beam Sonarmite BTX measures depths up to $75 \mathrm{~m}[6]$.

Hydrographic Institute of the Republic of Croatia (HHI) is responsible for carrying out the hydrographic activity of interest to the Republic of Croatia. They are official producers of nautical maps and harbor plans in the scale of 1: 8000 in Mercator projection. The plan for the port of Ploče is under label 53 in the HHI product catalogue and the latest version is from 2017 [17].

If the depths are determined for example, by means of a depth sounder mounted on the ship (direct measurement or conventional bathymetric measurement) [35], then the two types of survey measurements (single and multiple), can be applied with all their advantages and disadvantages briefly described here (Figure 5).

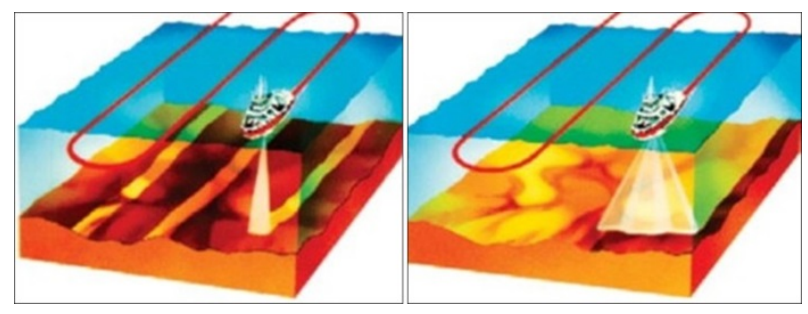

Fig. 5 The work principle of single-beam (left) and multi-beam (right) echo sounders [13] 


\subsection{SINGLE-BEAM ECHO SOUNDERS}

A single-beam echo sounder measures a single depth value in a unit of time and directly below the ship by previously defined profiles (Figure 5 - left). Compared to a multibeam echo sounder, its advantage in data collection is in lower equipment prices and easier processing of the data collected. Their accuracy is currently in centimetres [18]. However, it lacks in time longevity, which is a direct consequence of the survey area and the spacing between the profile and the necessity of using the interpolation method. Also, a single-strip depth measurement is not intended for recording broadband underwater floor, and the spatial resolution of data collected depends on three factors: sensor characteristics, water depth, and a defined recording plan [21]. For the purpose of this research, bathymetric measurements were performed with Sonarmite BTX single-beam echo sounder.

\subsection{MULTI-BEAM ECHO SOUNDER}

Compared to a single-beam, the advantages of multi-beam are: to measure multiple depth values at the same time, to cover larger surfaces and thus to produce an actual morphological model of the sea bottom without using the interpolation method (Figure 5 - right) [20]. Given the possibility of collecting more data in a shorter period, there are disadvantages such as the high equipment cost and the more demanding data processing. This technology is becoming a standard method of collecting bathymetric data to produce the highest quality navigational charts which would ensure the highest safety of navigation [14]. Their application is different: underwater construction [30], fish shoal monitoring [21], underwater archaeology, sanitation of underwater landfills [37]. Multi-beam EM 3002 D echo sounder was used in data collection process of the final stage.

\section{BATHYMETRIC OUTPUT RESULTS FOR VLAŠKA CHANNEL}

\subsection{CREATION OF MODELS OF INITIAL (ZERO) AND FINAL BATHIMETRIC SURVEY STAGE}

The data processing for bathymetric modelling of Vlaška channel was performed in five stages. The first stage was to collect and process data for the purpose of calculating the excavated volume. This stage also focused on data conversion from CAD $d w g$ formats to creation of the GIS data topology structures.

The second stage involved selection of the most appropriate geostatistical and deterministic interpolation methods in relation to the most appropriate spatial resolution. In the third stage, analysis and visualization of the derived digital depth models were performed. The fourth stage, was linked to interpretation of useful information about the given variables. In the last stage models showing calculated volume of excavated material were developed.

In summary the whole process included the following: CAD to GIS data conversion, topology check, depth correction for final 3-D model stage, interpolation selection, pixel size calculation and total excavation volume. The spatial extent of the study area included three zones: the waterway, the docks and the Vlaška channel.

For each zone, the depths of the excavation were defined. For example, for the waterway area zone, the required projected depth is $-17.855 \mathrm{~m}$. However, this is technically difficult to carry 
out due to the characteristics of the technologies used for excavation. All depths below -17.855 $m$ do not enter volume calculation, so they are reduced to the specified depth value. The above procedure is also conducted for the other two zones.

\subsection{INTERPOLATION OF THE OBTAINED RESULTS}

A Must be disjoint topology rule and Delete Identical tool were applied to avoid topology errors. This is a standard procedure when points are overlapping within the same feature class or subtype.

In order to obtain a continuous underwater surface, it was necessary to estimate the values in the unsampled areas by applying interpolation techniques. For this purpose, eight different interpolation methods were compared, by using the cross-validation method which helped to determine the most suitable interpolator for creating the raster model of the sea bed. In addition, the volume of excavation was calculated and the differences between the raster models were then compared. The efficiency (quality) of the interpolation methods was performed in two steps.

A number of 12262 points (Figure 6) are depicted in the initial (zero) stage, compared to 22492 (Figure 7) points shown in the final stage of the 3-D model of the sea floor. Using the Geostatistical Analyst extension, the interpolation parameters were optimized for each of the interpolation methods shown in Table 1 and Table 2.

Table 1 Parameters of the method of interpolation for the zero stage

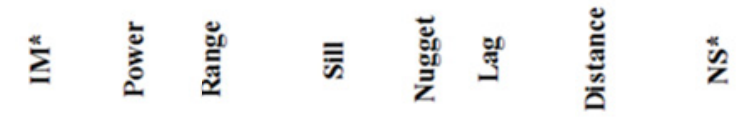

\begin{tabular}{l|rrrrrrr}
\hline IDW & 5.88 & & & & & 506.35 & 1 \\
LP & 1.00 & & & & & 18.79 & 1 \\
CRS & 0.54 & & & & & 506.35 & 1 \\
SWT & 0.00 & & & & & 506.35 & 1 \\
MQ & 3.35 & & & & & 506.35 & 1 \\
OK & & 9.86 & 0.44 & 0 & 1.23 & 14.79 & $4\left(45^{\circ}\right)$ \\
SK & & 1350.27 & 72.95 & 0 & 168.78 & 2025.36 & $4\left(45^{\circ}\right)$
\end{tabular}

*IM - method of interpolation, DEV - deviation, NS - number of sectors

Table 2 Parameters of the method of interpolation for the fimal stage

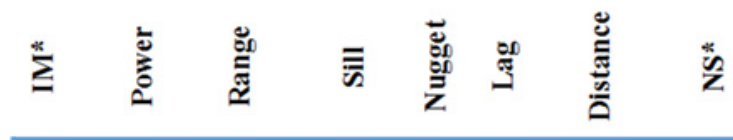

\begin{tabular}{l|rrlrrrr}
\hline IDW & 5.17 & & & & & 606.57 & 1 \\
LP & 1.00 & & & & & 7.4 & 1 \\
CRS & 44.92 & & & & & 606.57 & 1 \\
SWT & 64.70 & & & & & 606.57 & 1 \\
MQ & 4.12 & & & & & 606.57 & 1 \\
OK & & 15.42 & 0.63 & 0 & 1.93 & 23.14 & $4\left(45^{\circ}\right)$ \\
SK & & 128.90 & 6.17 & 0 & 16.11 & 192.32 & $4\left(45^{\circ}\right)$
\end{tabular}

*IM - method of interpolation, DEV - deviation, NS - number of sectors

Five deterministic (inverse distance weighted - IDW, local polynomial - LP, completely regularized spline - CRS, spline with tension - SWT, multiquadratic - MQ and two 
geostatistical methods of interpolation (ordinary kriging - OK, simple kriging - SK) were compared. The output results of deterministic methods were influenced by four parameters: (i) the distance exponent, (ii) the number of neighbours, (iii) the distance and (iv) type of sector. If, for example, the inverse distance of the exponent is 0 , then all neighbours have the same weight coefficient for the point for which the value is estimated. By increasing the distance exponent, the weight coefficient of distant points decreases.

For all deterministic methods, as a rule, the exponent of distance depends on the number of neighbours and type of sector. In all deterministic methods of interpolation for the initial (zero) stage data, the distance was $506.35 \mathrm{~m}$, except for the local polynomial $(18.79 \mathrm{~m}$ ), while for the final stage data it was $606.57 \mathrm{~m}$ (Table 1 and 2). A circular isotropic model is used, since it is assumed that the surrounding measured points are equally influenced by the output result.

Four different types of sectors can be used in the Geostatistical Analyst extension: the sector without division, the sector divided into four parts, the sector divided into four parts under a $45^{\circ}$ tilt and the sector divided into eight parts.

For example, according to the IDW method, at the distance exponent 2 and sector 1 (15 neighbouring points), the point for which the value is estimated is $19.501 \mathrm{~m}$. For sector 4 (60 neighbours, 15 in each sector) the value is $19.847 \mathrm{~m}$, for sector $4\left(45^{\circ}\right)$ (60 neighbours) the value is $20.16 \mathrm{~m}$ and for sector 8 (120 neighbours, 15 in each sector) is $19.628 \mathrm{~m}$. In accordance with Tobler rule, it was not necessary to over-increase the number of neighbouring points.

In all geostatistical methods, an experimental semivariogram or covariance integrates into a spherical model. An experimental semivariogram for the simple kriging method was based on 12262 bathymetric points. The data was analysed (compared) at a total distance of $2025.26 \mathrm{~m}$, or more precisely in 12 classes with a distance of $168.78 \mathrm{~m}$, which proved to be the most optimal solution. The deviation was $0 \mathrm{~m}$. The range narrowed the threshold to $1350.27 \mathrm{~m}$, which means that the spherical model then ceases to grow and levels, after which there is no spatial dependence of data.

In creating semivariograms, special attention was given to the theoretical model and the distance at which the data are compared. This affects the range, threshold and deviation, and thus directly the output of statistical indicators. Regarding the deterministic IM, the distance is geostatistically divided by 12 lags, as the optimal number emanating for the software used.

By analysing the height data for the initial (zero) stage, all the interpolation methods have shown satisfactory results and modelling suitablity, given the similarity of parameter values. The main reason for this is a small absolute difference in depth values, low sea level breakdown, and minimal portion of areas with sudden hikes. The standard deviation (SD) (zero stage), with respect to automatically optimized parameters, ranged from $0.135 \mathrm{~m}$ to $0.245 \mathrm{~m}$ (Table 3). 
Table 3 Results of the cross-validation method for zero stage

\begin{tabular}{|c|c|c|c|c|c|c|c|}
\hline$\Sigma$ & 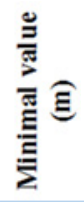 & 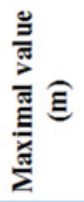 & 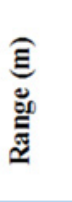 & 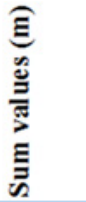 & 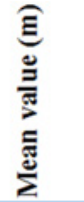 & 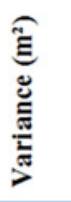 & 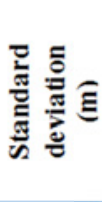 \\
\hline IDW & -2.56 & 2.39 & 4.95 & -8.30 & 0.00 & 0.03 & 0.164 \\
\hline LP & -2.15 & 1.19 & 3.35 & 53.51 & 0.00 & 0.06 & 0.245 \\
\hline CRS & -2.29 & 2.04 & 4.33 & -6.17 & -0.00 & 0.03 & 0.164 \\
\hline SWT & -2.02 & 1.81 & 3.83 & -7.26 & -0.00 & 0.02 & 0.136 \\
\hline MQ & -2.15 & 1.83 & 3.98 & -9.80 & -0.00 & 0.02 & 0.143 \\
\hline OK & -2.17 & 1.83 & 4.01 & -1.11 & 0.00 & 0.02 & 0.139 \\
\hline SK & -2.22 & 1.84 & 4.06 & -9.85 & -0.00 & 0.02 & 0.135 \\
\hline
\end{tabular}

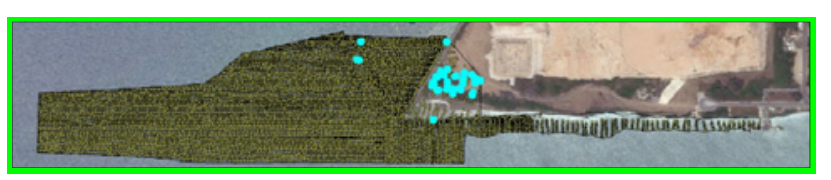

Fig. 6 Distribution of samples and maximum errors (light blue) in the SK model (zero state)

As expected, the geostatistical interpolation methods (OK and SK) were the best for all parameters. According to the analysed parameters, the SWT and the MQ were the best among the deterministic methods. Geostatistical methods have achieved more accurate results because of their working principle ( $\mu=$ known stationary mean, which is considered constant for the entire research area and calculated from the data average) and the maximum range between the depth value.

By visual comparison, it was found that models differ mostly in terms of the smoothness of the isobaths (Figure 8), which is logical given that the differences between selected parameters of the interpolation comparison are negligible. A more detailed visual analysis shows the result of an individual method (creating continuous surfaces at micro levels).

The minimum value (in meters) for the zero point stage, ranges from $-2.556 \mathrm{~m}$ (IDW) to -2.021 $m$ (SWT), and the maximum values (in $m$ ) from $1.811 \mathrm{~m}$ (SWT) to $2.395 \mathrm{~m}$ (IDW) (Figure 6).

By analysing the height data of the final stage it has been found that all the interpolation methods have shown satisfactory results and that they are useful for modelling, because they have similar values of the parameters (Table 4 and Figure 9). 
Table 4 Results of the cross-validation method for the final stage

\begin{tabular}{|c|c|c|c|c|c|c|c|}
\hline$\Sigma$ & 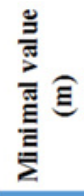 & 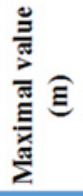 & 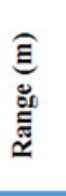 & 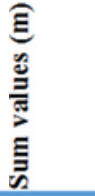 & 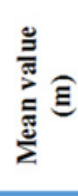 & 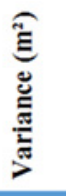 & 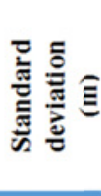 \\
\hline IDW & 3.68 & 2.11 & 5.79 & 26.96 & -0.00 & 0.02 & 0.153 \\
\hline LP & 3.84 & 2.19 & 6.03 & 285.22 & 0.01 & 0.03 & 0.184 \\
\hline CRS & -3.85 & 2.15 & 6.01 & 45.52 & 0.00 & 0.04 & 0.192 \\
\hline SWT & -3.86 & 2.17 & 6.04 & 40.80 & 0.00 & 0.04 & 0.197 \\
\hline MQ & 3.53 & 4.43 & 7.96 & 5.23 & 0.00 & 0.03 & 0.165 \\
\hline OK & -3.62 & 1.92 & 5.54 & 22.22 & 0.00 & 0.02 & 0.140 \\
\hline SK & -3.60 & 1.94 & 5.53 & 37.81 & 0.00 & 0.02 & 0.140 \\
\hline
\end{tabular}

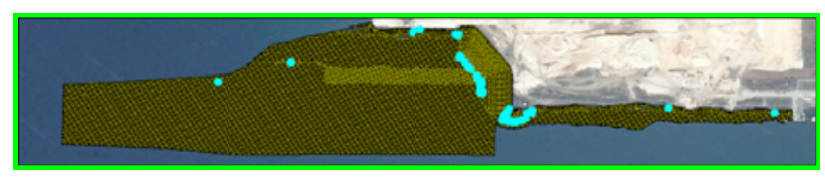

Fig. 7 Distribution of samples (light blue) and maximum errors in the SK model (final stage)

The standard deviation (final stage), with respect to the auto-optimized parameters, ranged from $0.140 \mathrm{~m}$ (OK and SK) to $0.197 \mathrm{~m}$ (SWT) meters.

In general, geostatistical interpolation methods have proved to be a better choice, while according to the analysed parameters of the deterministic interpolation methods, MQ and IDW proved to be the best.

The minimum value (in meters) for the final stage of the points ranges from $-3.864 \mathrm{~m}$ (SWT) to $-3.528 \mathrm{~m}(\mathrm{MQ})$, and the maximum values from $1.924 \mathrm{~m}(\mathrm{OK})$ to $4.430 \mathrm{~m}(\mathrm{MQ})$ (Figure 7). The best method for all indicators for 22492 points are simple (SK) and ordinary kriging (OK). The standard deviation for these methods is $0.140 \mathrm{~m}$. The worst results or the largest standard deviation $(0.197 \mathrm{~m})$, was achieved by the spline with tension method (SWT). 

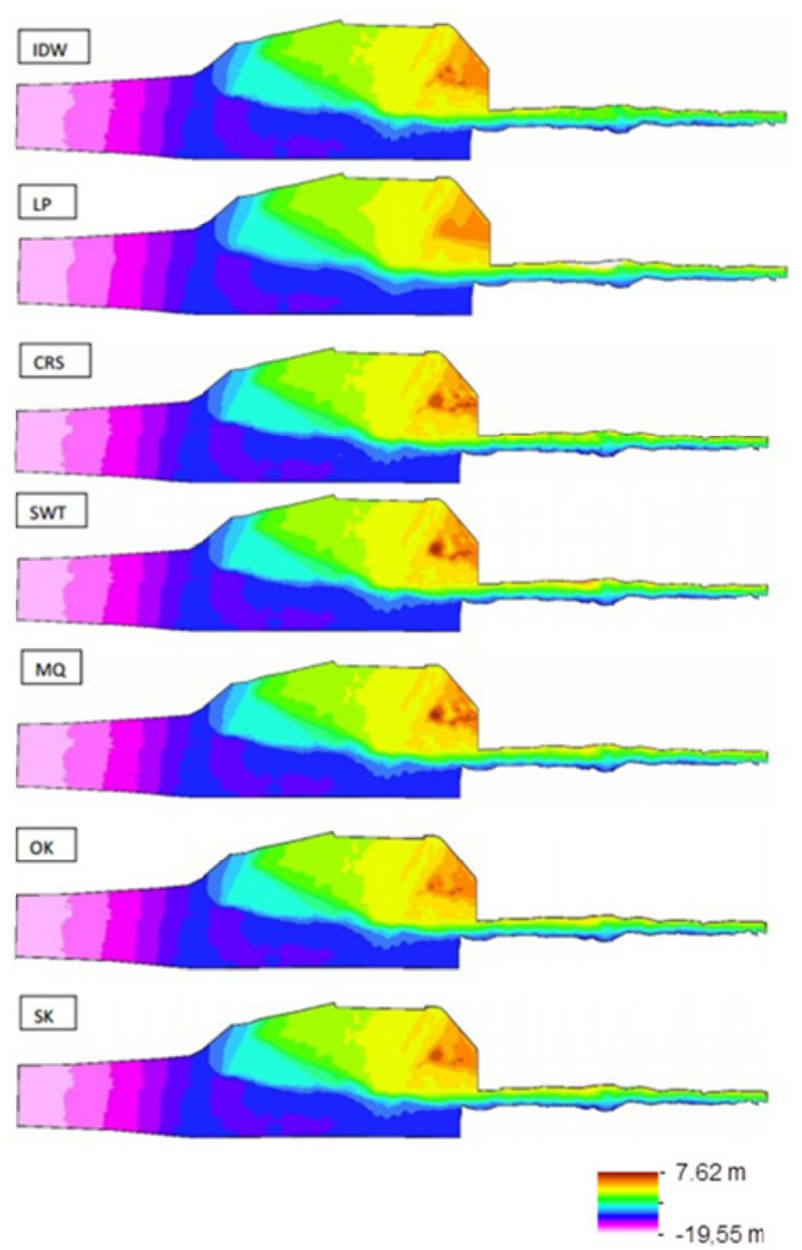

Fig. 8 Two-dimensional representations of the Vlaška channel - initial (zero) stage

When taking into account the results of the cross-validation method for the initial (zero) and final stages, OK and SK were used for volume calculation in order to achieve the best results. The MQ deterministic interpolation method was used as the second best next to geostatistic interpolation methods, for both the initial (zero) and the final stage, because of its better radial core function. The SWT method is discarded because it had a good result for the initial stage only, and shown less accurate results for the final stage.

\subsection{CHOOSING A SPATIAL RESOLUTION}

Choosing a spatial resolution represents one of the challenges in the process of digital relief modelling. The aim is to find the most suitable spatial resolution, in order to generate the best underwater relief model for the Vlaška channel. In this process, three methods were applied to determine the pixel size: McCullagh's method, The Control points method, and The Sample density method. Tables 5 and 6 shows that there are significant differences between the methods. 

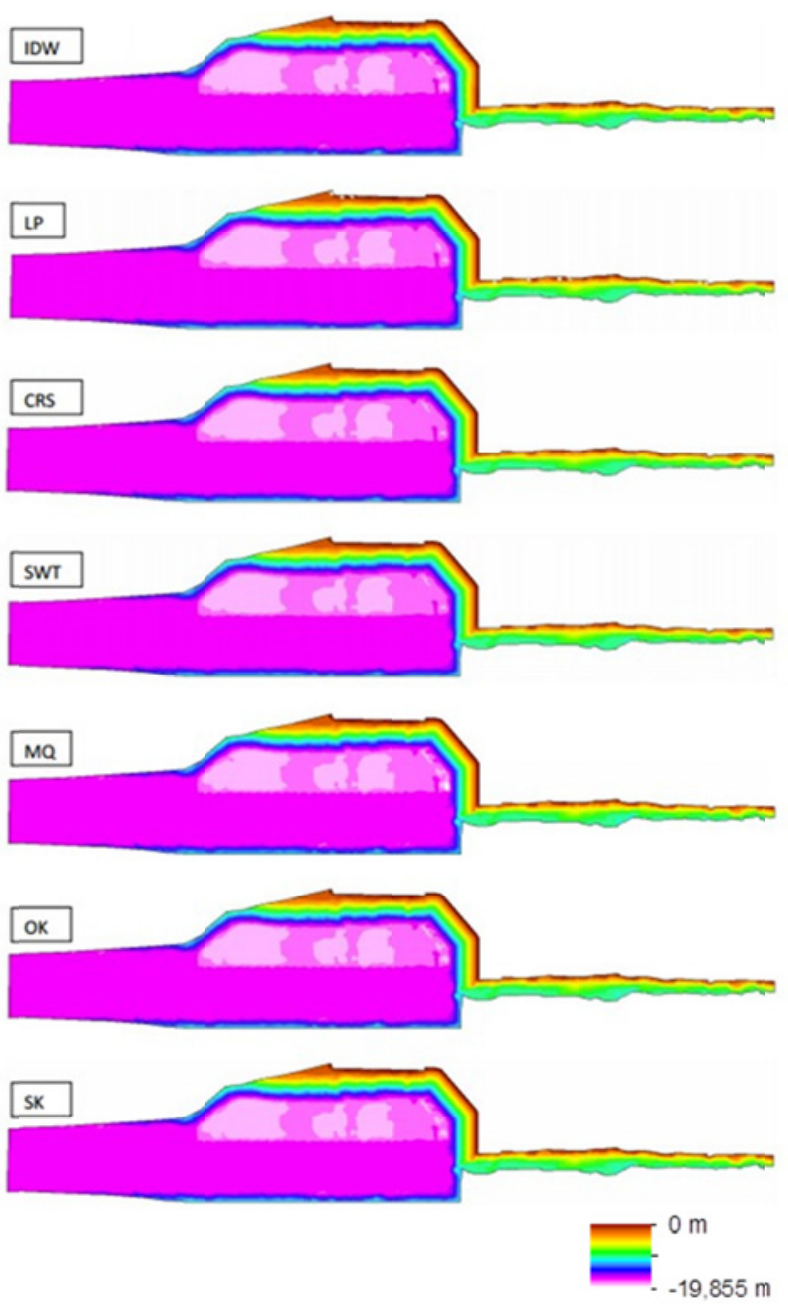

Fig. 9 Two-dimensional representations of the Vlaška channel - final stage

Table 5 Spatial resolution selection methods for intial (zero) stage

\begin{tabular}{c|cccc|} 
Method & Formula & $\boldsymbol{n}^{*}$ & $\boldsymbol{A}^{*}\left(\mathbf{m}^{2}\right)$ & $\boldsymbol{R P S}^{*}$ \\
\hline McCullagh's & $P=\sqrt{\frac{A}{n}}$ & 12.262 & $187.245,93$ & 3,9 \\
$\begin{array}{c}\text { Inspection Density } \\
\begin{array}{c}\text { Point pattern analysis } \\
\text { (random) }\end{array}\end{array}$ & $P=0,0791 * \sqrt{\frac{A}{n}}$ & 12.262 & $187.245,93$ & 0,3 \\
$\begin{array}{c}\text { Point pattern analysis } \\
\text { (regular) }\end{array}$ & $P=0,025 * \sqrt{\frac{A}{n}}$ & 12.262 & $187.245,93$ & 1,0 \\
\end{tabular}

${ }_{n}=$ number of points; $A=$ area; $R P S=$ recommended pixel size

The values in the zero-stage model span from 0,3 $\mathrm{m}$ (Inspection Density) up to 3,9 $\mathrm{m}$ (McCullagh's method) (Table 5), and for the final stage, from 0,2 $\mathrm{m}$ (Inspection Density) to 2,9 $m$ (McCullagh's method) (Table 6). 
A. Šiljeg, B. Cavrić, I. Marić, M. Barada: GIS modelling of bathymetric data in the construction of port terminals - the example of Vlaška channel in the Port of Ploče, Croatia

Table 6 Spatial resolution selection methods for final stage

\begin{tabular}{|c|c|c|c|c|}
\hline Method & Formula & $n^{*}$ & $A^{*}\left(m^{2}\right)$ & $R_{P S}{ }^{*}$ \\
\hline McCullagh's & $R P S=\sqrt{\frac{A}{n}}$ & 22.492 & $187.245,93$ & 2,9 \\
\hline Inspection Density & $R P S=0,0791 * \sqrt{\frac{A}{n}}$ & 22.492 & $187.245,93$ & 0,2 \\
\hline $\begin{array}{c}\text { Point pattern } \\
\text { analysis (random) }\end{array}$ & $R P S=0,025 * \sqrt{\frac{A}{n}}$ & 22.492 & $187.245,93$ & 0,7 \\
\hline $\begin{array}{l}\text { Point pattern } \\
\text { analysis (regular) }\end{array}$ & $R P S=0,5^{*} \sqrt{\frac{A}{n}}$ & 22.492 & $187.245,93$ & 1,4 \\
\hline
\end{tabular}

${ }^{*} n=$ number of points; $A=$ area; RPS=recommended pixel size

After analysing the presented statistical and visual methods of validation, it was concluded that the most appropriate technique for calculating and visualizing initial (zero) and final stage is the McCullagh's method. It shows good results, but in certain areas it overly smooths and generalizes the relief forms. At the same time, the Inspection Density method shows greatest drawbacks which are observed in the more levelled areas, where the problem of the so called "Prussian helmets" occurs.

\subsection{CALCULATING VOLUMES OF EXCAVATED MATERIALS FOR THE INTIAL (ZERO) AND FINAL STAGES}

A volume is expressed in cubic units and can be defined as the enclosed space between two three-dimensional surfaces. The total excavated volume referenced in this paper is calculated as the difference between the initial sea bed floor and the final sea bed floor surface. Today, the methods of volume calculation have greatly improved $[1,7]$.

Output results of the volume depend on: data collection methods; water body floor discrepancy, density and point layout; spatial resolution (pixel size), algorithms used, and the selected interpolation method. The goal of determining the difference in volume between the intial (zero) (volume 1) and the final stage (volume 2) is set as a key objective of the research. The total volume difference was calculated for an area of $187245.93 \mathrm{~m}^{2}$ (Figure 8) consisting of four zones: (i) Under the dock (50824.04 $\left.\mathrm{m}^{2}-27.14 \%\right)$; (ii) Access bridge $\left(12297.15 \mathrm{~m}^{2}-\right.$ 6.57\%); (iii) Channel (105420.19 $\left.\mathrm{m}^{2}-56.30 \%\right)$ and (iv) Slope mitigation (18704.55 $\left.\mathrm{m}^{2}-9.99 \%\right)$ (Figure 10).

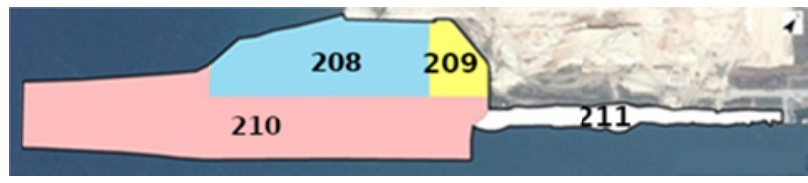

Fig. 10 Areas within which the volume of excavated material is determined (208 - under the dock; 209 access bridge; 210 - channel; 211 - slope mitigation) 
For each of them, the difference between the intial (zero) and the final stage was calculated. The aim was to determine the total volume of excavated material for all four zones, based on the following formula:

$$
V_{a}=\left(V_{2}-V_{1}\right)+V_{1}(\text { pos. })
$$

where:

$V_{a}=$ volume of excavated material in a given zone

$V_{2}=$ final stage volume of a given zone (below sea level - negative volume)

$V_{1}=$ volume of initial (zero) stage of a given zone (below sea level - negative volume)

$V_{1 \text { (pos.) }}=$ volume of intial (zero) stage of a given zone (above sea level - positive volume).

After calculating the volume of the excavated material for each specific zone, the obtained output results were summed up to determine the total volume of $187245.93 \mathrm{~m}^{2}$ of surface area material.

Three Newton-Cotes formulae were used for calculation of the volumes integrated into the Surfer (trial) programme and based on: (i) extended trapezoidal rule; (ii) extended Simpson's $1 / 3$ rule and (iii) the extended Simpson's 3/8 rule [31]. The most important factor influencing the output of the volume is spatial resolution. Specifically, the smaller it is, the more accurate the calculation should be, because both the transition and the vertical skips between the pixels will be smaller [36]. Through this procedure, an attempt was made to investigate the accuracy and determine the variability of the output results. It is also evident how the choice of specific interpolation method affects the value of output results, in this case the volume of excavated material.

Tables 7 and 8 show output results of volumes (below and above sea level) for initial (zero) and final stages based on selected deterministic (NN and MQ) (Table 7) and geostatistic (OK and SK) (Table 8) interpolation methods. The final stage model does not generate volume values above sea level because the generated altitudes in the model do not exceed $0 \mathrm{~m}$ (sea level) (max. value of altitude datum is 0,75 $\mathrm{m}$ for March, 2019 - Mareographic Station Ploče), meaning that all of the material (volume above the sea level) generated in the zero stage model for the construction of the dock was removed.

In the area of the Ploče port basin, in the ten-year return period, the amplitude is approximately $1.22 \mathrm{~m}$, while the maximum amplitude of $1.42 \mathrm{~m}$ is possible over a period of one hundred years [33]. Table 9 shows, according to the specific interpolation method, how much material was excavated in each zone. 
A. Šiljeg, B. Cavrić, I. Marić, M. Barada: GIS modelling of bathymetric data in the construction of port terminals - the example of Vlaška channel in the Port of Ploče, Croatia

Table 7 Volume $\left(m^{3}\right)$ for zero and final stage according to deterministic IMs

\begin{tabular}{|c|c|c|c|c|c|}
\hline \multicolumn{6}{|c|}{ ZERO STATE } \\
\hline \multirow{3}{*}{ Newton-Cotes' formulas } & \multirow{2}{*}{\multicolumn{4}{|c|}{$\begin{array}{l}\text { NN (Natural neighbour) } \\
\text { Volume (below sea level) }\end{array}$}} & \multirow{3}{*}{ TOTAL } \\
\hline & & & & & \\
\hline & Zone 208 & Zone 209 & Zone 210 & Zone 211 & \\
\hline Trapezoid rule & 184682.71 & 378.95 & 1255881.31 & 96044.38 & 1536987.35 \\
\hline Simpson's rule & 184466.13 & 377.32 & 1255609.02 & 96085.93 & 1536538.40 \\
\hline Simpson's $3 / 8$ rule & 184549.44 & 395.79 & 1255432.29 & 95993.81 & 1536371.33 \\
\hline Arithmetic mean & 184566.09 & 384.02 & 1255640.87 & 96041.37 & 1536632.36 \\
\hline \multirow{3}{*}{ Newton-Cotes' formulas } & \multicolumn{4}{|c|}{ Volume } & \multirow{3}{*}{ TOTAL } \\
\hline & \multicolumn{4}{|c|}{ (above sea level) } & \\
\hline & Zone 208 & Zone 209 & Zone 210 & Zone 211 & \\
\hline Trapezoid rule & 256.59 & 17995.14 & 289.89 & 127.06 & 18668.68 \\
\hline Simpson's rule & 473.17 & 17996.77 & 562.16 & 85.81 & 19117.91 \\
\hline Simpson's $3 / 8$ rule & 389.86 & 17978.30 & 738.91 & 177.63 & 19284.70 \\
\hline Arithmetic mean & 373.21 & 17990.07 & 530.32 & 130.17 & 19023.76 \\
\hline \multicolumn{6}{|c|}{ FINAL STATE } \\
\hline \multirow{3}{*}{ Newton-Cotes' formula } & \multirow{2}{*}{\multicolumn{4}{|c|}{$\begin{array}{l}\text { NN (Natural neighbour) } \\
\text { Volume (bblow sea level) }\end{array}$}} & \multirow{3}{*}{ TOTAL } \\
\hline & & & & & \\
\hline & Zone 208 & Zone 209 & Zone 210 & Zone 211 & \\
\hline Trapezoid rule & 803130.49 & 141877.81 & 1829550.37 & 140283.40 & 2914842.11 \\
\hline Simpson's rule & 802935.89 & 141478.57 & 1828980.95 & 140225.80 & 2913621.17 \\
\hline Simpson's $3 / 8$ rule & 802828.98 & 141583.39 & 1829393.53 & 140202.00 & 2914007.87 \\
\hline Arithmetic mean & 802965.12 & 141646.59 & 1829308.28 & 140237.06 & 2914157.05 \\
\hline \multicolumn{6}{|c|}{ ZERO STATE } \\
\hline \multirow{3}{*}{ Newton-Cotes' formulas } & \multirow{2}{*}{\multicolumn{4}{|c|}{$\begin{array}{c}\text { MQ (Multiquadratic) } \\
\text { Volume (below sea level) }\end{array}$}} & \multirow{3}{*}{ TOTAL } \\
\hline & & & & & \\
\hline & Zone 208 & Zone 209 & Zone 210 & Zone 211 & \\
\hline Trapezoid rule & 184581.48 & 460.08 & 1255865.47 & 96235.71 & 1537142.74 \\
\hline Simpson's rule & 184364.30 & 467.71 & 1255592.83 & 96278.47 & 1536703.31 \\
\hline Simpson's $3 / 8$ rule & 184446.98 & 464.86 & 1255423.82 & 96187.02 & 1536522.68 \\
\hline Arithmetic mean & 184464.25 & 464.22 & 1255627.37 & 96233.73 & 1536789.58 \\
\hline \multirow{2}{*}{ Newton-Cotes' formulas } & \multicolumn{4}{|c|}{ Volume (above sea level) } & \multirow{2}{*}{ TOTAL } \\
\hline & Zone 208 & Zone 209 & Zone 210 & Zone 211 & \\
\hline Trapezoid rule & 271.90 & 17805.73 & 317.61 & 370.85 & 18766.09 \\
\hline Simpson's rule & 489.08 & 17798.10 & 590.24 & 328.09 & 19205.51 \\
\hline Simpson's $\mathbf{3 / 8}$ rule & 406.40 & 17791.95 & 759.28 & 419.53 & 19377.16 \\
\hline Arithmetic mean & 389.13 & 17798.59 & 555.71 & 372.82 & 19377.16 \\
\hline \multicolumn{6}{|c|}{ FINAL STATE } \\
\hline \multirow{3}{*}{ Newton-Cotes' formulas } & \multirow{2}{*}{\multicolumn{4}{|c|}{$\begin{array}{c}\text { MQ (Multiquadratic) } \\
\text { Volume (below sea level) }\end{array}$}} & \multirow{3}{*}{ TOTAL } \\
\hline & & & & & \\
\hline & Zone 208 & Zone 209 & Zone 210 & Zone 211 & \\
\hline Trapezoid rule & 803130.09 & 141944.44 & 1829556.68 & 140310.20 & 2914941.44 \\
\hline Simpson's rule & 802919.63 & 141545.04 & 1828982.77 & 140271.00 & 2913718.41 \\
\hline Simpson's $3 / 8$ rule & 802817.93 & 141644.74 & 1829398.85 & 140223.40 & 2914084.96 \\
\hline Arithmetic mean & 802955.88 & 141711.41 & 1829312.77 & 140268.21 & 2914248.27 \\
\hline
\end{tabular}

According to the obtained results, most of the material is excavated in the two largest zones (208 - Below the dock and 210 - Channel), which make up 83.44\% of the total area of the entire research area.

In zone 208, the largest volume was generated by the MQ method and the lowest by the NN method. In zone 209 (access bridge), according to the arithmetic mean of all four methods of interpolation, $159231.64 \mathrm{~m}^{3}$ of material was excavated. The largest volume was generated by the SK method and the lowest by the MQ method. The range is $313.31 \mathrm{~m}^{3}$. In zone 210 (channel), according to the arithmetic mean of all four methods of interpolation, $574241.76 \mathrm{~m}^{3}$ of material was excavated. The largest volume was generated by the OK method and the lowest by the NN method. The range is $9.34 \mathrm{~m}^{3}$. In zone 211 (softening of the curve), according to the arithmetic mean of all four methods of interpolation, $44578.61 \mathrm{~m}^{3}$ of material was excavated. The largest volume was generated by the OK method and the lowest by the NN method. The range is $768.03 \mathrm{~m}^{3}$. 
A. Šiljeg, B. Cavrić, I. Marić, M. Barada: GIS modelling of bathymetric data in the construction of port terminals - the example of Vlaška channel in the Port of Ploče, Croatia

Table 8 Volume $\left(m^{3}\right)$ for zero and final stage according to geostatistical IM

\begin{tabular}{|c|c|c|c|c|c|}
\hline \multicolumn{6}{|c|}{ ZERO STATE } \\
\hline \multirow{3}{*}{ Newton-Cotes' formulas } & \multirow{2}{*}{\multicolumn{4}{|c|}{$\begin{array}{c}\text { SK (Simple kriging) } \\
\text { Volume (below sea level) }\end{array}$}} & \multirow{3}{*}{ TOTAL } \\
\hline & & & & & \\
\hline & Zone 208 & Zone 209 & Zone 210 & Zone 211 & \\
\hline Trapezoid rule & 184578.69 & 395.30 & 1255912.64 & 95786.97 & 1536673.60 \\
\hline Simpson's rule & 184360.25 & 398.27 & 1255642.35 & 95827.23 & 1536228.10 \\
\hline Simpson's $3 / 8$ rule & 184447.26 & 410.49 & 1255466.90 & 95738.95 & 1536063.60 \\
\hline Arithmetic mean & 184462.07 & 401.35 & 1255673.96 & 95784.38 & 1536321.77 \\
\hline \multirow{2}{*}{ Newton-Cotes' formulas } & \multicolumn{4}{|c|}{ Volume (above sea level) } & \multirow{2}{*}{ TOTAL } \\
\hline & Zone 208 & Zone 209 & Zone 210 & Zone 211 & \\
\hline Trapezoid rule & 265.07 & 18115.01 & 280.29 & 232.47 & 18892.84 \\
\hline Simpson’s rule & 483.51 & 18112.04 & 550.58 & 192.21 & 19338.34 \\
\hline Simpson's $3 / 8$ rule & 396.50 & 18099.82 & 726.03 & 280.49 & 19502.84 \\
\hline Arithmetic mean & 381.69 & 18108.96 & 518.97 & 235.06 & 19244.67 \\
\hline \multicolumn{6}{|c|}{ FINAL STATE } \\
\hline \multirow{3}{*}{ Newton-Cotes' formulas } & \multirow{2}{*}{\multicolumn{4}{|c|}{$\begin{array}{l}\text { SK (Natural neighbour) } \\
\text { Volume (below sea level) }\end{array}$}} & \multirow{3}{*}{ TOTAL } \\
\hline & & & & & \\
\hline & Zone 208 & Zone 209 & Zone 210 & Zone 211 & \\
\hline Trapezoid rule & 803089.91 & 141882.12 & 1829656.19 & 140080.73 & 2914708.95 \\
\hline Simpson's rule & 802888.47 & 141483.17 & 1829092.10 & 140027.58 & 2913491.32 \\
\hline Simpson's $3 / 8$ rule & 802786.02 & 141589.17 & 1829500.15 & 140000.89 & 2913876.23 \\
\hline Arithmetic mean & 802921.47 & 141651.49 & 1829416.15 & 140036.40 & 2914025.50 \\
\hline \multicolumn{6}{|c|}{ ZERO STATE } \\
\hline \multirow{3}{*}{ Newton-Cotes' formulas } & \multirow{2}{*}{\multicolumn{4}{|c|}{$\begin{array}{c}\text { OK (Ordinary kriging) } \\
\text { Volume (below sea level) }\end{array}$}} & \multirow{3}{*}{ TOTAL } \\
\hline & & & & & \\
\hline & Zone 208 & Zone 209 & Zone 210 & Zone 211 & \\
\hline Trapezoid rule & 184598.70 & 390.10 & 1255843.37 & 95297.80 & 1536129.97 \\
\hline Simpson's rule & 184381.04 & 398.76 & 1255574.30 & 95349.35 & 1535703.45 \\
\hline Simpson's $3 / 8$ rule & 184467.38 & 407.11 & 1255397.56 & 95244.37 & 1535516.42 \\
\hline Arithmetic mean & 184482.37 & 398.66 & 1255605.08 & 95297.17 & 1535783.28 \\
\hline \multirow{2}{*}{ Newton-Cotes' formulas } & \multicolumn{4}{|c|}{ Volume (above sea level) } & \multirow{2}{*}{ TOTAL } \\
\hline & Zone 208 & Zone 209 & Zone 210 & Zone 211 & \\
\hline Trapezoid rule & 256.40 & 18005.63 & 284.42 & 209.92 & 18756.37 \\
\hline Simpson's rule & 474.06 & 17996.97 & 553.48 & 158.38 & 18708.83 \\
\hline Simpson's $3 / 8$ rule & 387.72 & 17988.62 & 730.22 & 263.46 & 19370.02 \\
\hline Arithmetic mean & 322.06 & 17997.07 & 522.71 & 210.59 & 19052.43 \\
\hline \multicolumn{6}{|c|}{ FINAL STATE } \\
\hline \multirow{3}{*}{ Newton-Cotes' formulas } & \multirow{2}{*}{\multicolumn{4}{|c|}{ OK (Ordinary kriging) }} & \multirow{3}{*}{ TOTAL } \\
\hline & & & ow sea level) & & \\
\hline & Zone 208 & Zone 209 & Zone 210 & Zone 211 & \\
\hline Trapezoid rule & 803129.19 & 141901.30 & 1829589.48 & 140224.62 & 2914844.59 \\
\hline Simpson’s rule & 802929.58 & 141502.30 & 1829025.25 & 140172.26 & 2913629.39 \\
\hline Simpson's $3 / 8$ rule & 802825.58 & 141608.30 & 1829433.58 & 140144.51 & 2914011.97 \\
\hline Arithmetic mean & 802961.45 & 141670.63 & 1829349.44 & 140180.46 & 2914161.98 \\
\hline
\end{tabular}

Table 9 Volume $\left(m^{3}\right)$ of excavated material per zone

\begin{tabular}{c|ccccc} 
Zone & \multicolumn{5}{c}{$\mathbf{V}_{\mathbf{a}}$-Dredged material $\left(\mathbf{m}^{\mathbf{3}}\right)$} \\
\hline \multirow{3}{*}{$\mathbf{2 0 8}$} & NN & MQ & SK & OK & Mean \\
$\mathbf{2 0 9}$ & 159252.64 & 159045.78 & 159359.09 & 159269.05 & 159231.64 \\
$\mathbf{2 1 0}$ & 574197.73 & 574241.1 & 574261.15 & 574267.07 & 574241.7625 \\
211 & 44325.85 & 44407.3 & 44487.41 & 45093.88 & 44578.61 \\
TOTAL & 1396548.45 & 1396574.94 & 1396948.74 & 1397431.14 & $\mathbf{1 3 9 6 8 7 5 . 8 2}$ \\
\cline { 2 - 6 } & & & & &
\end{tabular}

By calculating the volume of excavated material by zones (arithmetic mean value), the total volume of material that is excavated in the entire exploration area of $187245.93 \mathrm{~m}^{2}$ is obtained. The total volume (mean value of all IMs) of excavated material is $1396875.82 \mathrm{~m}^{3}$ (Table 9). It should be noted that the total calculation does not include the amount of material excavated in the "leg" area. 


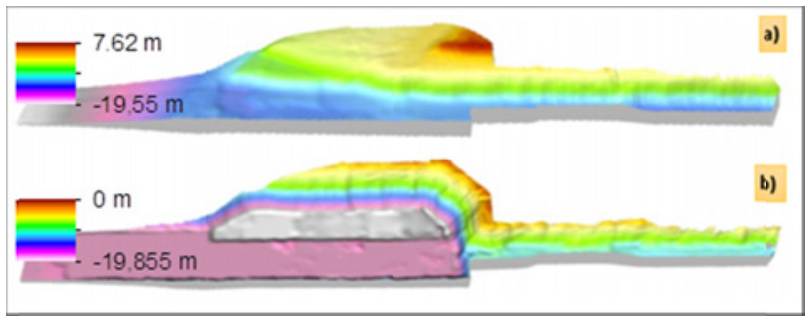

Fig. 11 Perspective view a) zero and b) final stage

Table 10 Dredged volume $\left(\mathrm{m}^{3}\right)$ of material for the entire area according to the IMs used

\begin{tabular}{c|cccc|}
$\begin{array}{c}\text { Method of } \\
\text { interpolation }\end{array}$ & $\mathbf{V}_{\mathbf{2}}$ & $\mathbf{V}_{\mathbf{1}}$ & $\mathbf{V}_{\mathbf{1}(\mathbf{p o z} \text { ) }}$ & $\mathbf{V}_{\mathbf{a}}$ \\
\hline NN & 2914157.05 & 1536632.36 & 19023.76 & 1396548.45 \\
MQ & 2914248.27 & 1536789.58 & 19116.25 & 1396574.95 \\
OK & 2914161.98 & 1535783.28 & 19052.43 & 1397431.13 \\
SK & 2914025.50 & 1536321.43 & 19244.67 & 1396948.74 \\
Arithmetic mean & & & & $\mathbf{1 3 9 6 8 7 5 . 8 2}$ \\
\cline { 3 - 5 } & & & &
\end{tabular}

Table 10 shows the total volume of dredged material (no foot) for all IMs used. The highest result was achieved by the OK method $\left(1397431.13 \mathrm{~m}^{3}\right)$ and the lowest by the NN method $\left(1396548.45 \mathrm{~m}^{3}\right)$. The range is $882.68 \mathrm{~m}^{3}$. It is noticeable that geostatistical interpolation methods, which according to the cross-validation method are recognized as more accurate (smaller standard deviations). generate somewhat higher volume values. If the arithmetic mean was calculated only for $\mathrm{OK}$ and SK. the total volume of dredged material would be $1397189.94 \mathrm{~m}^{3}$.

Following the results for accuracy assessment of IMs (Tables 3 and 4) we suggest to take geostatistical based (SK and OK) volume calculations as relevant for further applications in construction.

\section{CONCLUSION}

This paper presented the importance of bathymetric survey using the case study of the construction of the new bulk cargo port terminal at the Vlaška channel in the Croatian Sea Port of Ploče. Based on the data of the depths of initial (zero) (12262 points) and final stage (22492 points), the digital depth models for the defined zones $(208,209,210$ and 211) were derived. The volumes of initial (zero) and final stages were calculated based on the models generated from four selected interpolation methods (2 geostatistical - OK and SK and 2 deterministic $\mathrm{NN}$ and MQ). In this way, it was attempted to determine the accuracy and the variability of the output results, i.e. how the choice of a certain interpolation method influences the output results (volume of the excavated material). Geostatistical interpolation method showed better performance when considering standard deviation, as one of the most frequent indicators of model accuracy. It is particularly related to SK and OK.

The volume within each zone is represented by all three Newton-Cotes formulae, however, since each of the formulae shows a certain error in the volume estimation, the arithmetic mean for the three formulae was calculated and used as the final indicator. The total volume of the excavated material, which was calculated as the difference between the initial (zero) and the 
final stage, is $1397189.94 \mathrm{~m}^{3}$. It is a mean value of OK and SK based models, since they were marked as the most relevant (lowest SD).

\section{ACKNOWLEDGEMENTS}

We would like to thank construction companies Mucić \& Co. d.o.o. and Viadukt d.d. as well as Croatian Hydrography Institute (HHI) for their cooperation and data sharing.

This work has been supported in part by the Croatian Science Foundation under the project UIP-2017-05-2694.

\section{REFERENCES}

[1] S. Ahmed, Water Volume Calculation of Hill Country Trinity Aquifer Blanco, Hays, and Travis Counties, Central Texas GIS and GPS Applications in Earth Science, available at: http://www.geo.utexas.edu/courses/371C/project/2010F/Ahmed Project.pdf, (last access: 6 May 2012), 2010.

[2] H. Baričević, T.P. Jugović, S. Vilke, Cargo in transport, Sveučilište u Rijeci, Pomorski fakultet, Rijeka, 2010.

[3] D. Bolanča, Pravni status luke Ploče u sklopu hrvatskih relevantnih propisa i Međunarodnog sporazuma o slobodnom tranzitu kroz teritorij Republike Hrvatske i iz luke Ploče i kroz teritorij Bosne i Hercegovine u Neumu (1998.), Pomorski zbornik, Vol. 39, No. 1, pp. 17-56, 2001.

[4] COWI: Marine and coastal engineering, available at: http://www.cowi.com/menu/service/BridgeTunnelandMarineStructures/Documents/0211700-023e-10d Marine.pdf (last access: 4 July 2017), 2010.

[5] K. Cullinane, W.T. Fei, S. Cullinane, Container terminal development in Mainland China and its impact on the competitiveness of the port of Hong Kong, Transport Reviews, Vol. 24, No. 1, pp. 33-56, 2004. https://doi.org/10.1080/0144164032000122334

[6] H.M. Dierssen, A.E. Theberge, Bathymetry: Assessing Methods, In: Encyclopedia of Natural Resources, Vol II - Water and Air, Ed.: Y. Wang. Taylor \& Francis Group, pp. 1-8, 2014.

[7] G. Diolaiuti, M.P. Kirkbride, C. Smiraglia, D.I.C. D'Agata, L. Nicholson, Calving processes and lake evolution at Miage Glacier (Mont Blanc, Italian Alps), Annals of Glaciology, Vol. 40, No. 1, pp. 207-214, 2005. https://doi.org/10.3189/172756405781813690

[8] Č. Dundović, B. Kesić, I. Kolanović, Značenje i uloga izgradnje prometnih koridora u razvitku luke Ploče, Pomorski zbornik, Vol. 43, No. 1, pp. 113-130, 2005.

[9] Č. Dundović, I. Kolanović, Ocjena i tendencije razvitka prekrcajnih kapaciteta hrvatskih morskih luka, Pomorski zbornik, Vol. 39, No. 1, pp. 137-152, 2001.

[10] Earth Explorer, https://earthexplorer.usgs.gov/ (last access: 3 July 2017), 2017.

[11] EKONERG, Studija o utjecaju na okoliš postrojenja za proizvodnju biodizela u luci Ploče, EKONERG - Institut za energetiku i zaštitu okoliša, Zagreb, available at: http://www.eib.org/infocentre/register/all/64522910.pdf, (last access: 1 July 2017), 2013. 
[12] Elhassan, Bathymetric Techniques, Civil Eng. Dept., King Saud University, Riyadh, KSA, available

https://www.fig.net/resources/proceedings/fig proceedings/fig2015/ppt/TS04A/TS04A e lhassan 7716 ppt.pdf, (last access: 1 July 2017), 2015.

[13] EL-Hattab, Single beam bathymetric data modelling techniques for accurate maintenance dredging, The Egyptian Journal of Remote Sensing and Space Science, Vol. 17, No. 2, pp. 189-195, 2014. https://doi.org/10.1016/j.ejrs.2014.05.003

[14] V. Ernstsen, R. Noormets, D. Hebbeln, A. Bartholomé, B. Flemming, Precision of highresolution multibeam echo sounding coupled with high-accuracy positioning in a shallow water coastal environment, Geo-Marine Letters, Vol. 26, No. 3, pp. 141-149, 2006. https://doi.org/10.1007/s00367-006-0025-3

[15] H.G. Greene, J.J. Bizzarro, V.M. O'Connell, C.K. Brylinsky, Construction of digital potential marine benthic habitat maps using a coded classification scheme and its application. Geological Association of Canada Special Paper, Vol. 47, No. 1, pp. 141-155, 2007.

[16] Hrga, R. Vlahov, D. Silov, Pomorsko tržište rasutog i generalnog terete, Pomorski zbornik, Vol. 45, No. 1, pp. 61-70, 2008.

[17] Hydrographic Institute of the Reublic of Croatia (HHI), Catalogue of nautical charts and pulications (Ed. in chief: V. Kolić), HHI, Split, 2018.

[18] IHO: Manual of Hydrography, Publication M-13, $1^{\text {st }}$ edition, International Hidrographic Bureau, Monaco, 2005.

[19] J. Jandrik, Izvješće o sigurnosti, naftni terminali Federacije Bosne i Hercegovine u Pločama. Doctoral dissertation, Karlovac University of Applied Sciences, Department of Wildlife Management and Nature Conservation, 2015.

[20] M. Kang, Analysis of the ME70 multibeam echosounder data in echoview - current capability and future directions, Journal of Marine Science and Technology, Vol. 19, No. 3, pp. 312-321, 2011.

[21] Kearns, J. Breman, Bathymetry - The art and science of seafloor modeling for modern applications, In: Ocean Globe, Ed.: Breman J., ESRI Press, Redlands, pp. 1-36, 2010.

[22] P. Knox, D. Anglin, A. Cornett, E. Hall, M. Armstrong, Role of physical modelling in developing a new cruise ship terminal at an exposed site, Coastal Engineering Proceedings, Vol. 1, No. 34, pp. 80, 2014. https://doi.org/10.9753/icce.v34.structures.80

[23] S. Kos, D. Brčić, J. Karmelić, Strukturna analiza kontejnerizacije hrvatskih luka. Pomorstvo: (Scientific Journal of Maritime Research), Vol. 24, No. 2, pp. 189-209, 2010.

[24] Luka Ploče, http://www.luka-ploce.hr/hr/o-luci/razvoj-i-investicije/, (last access: 2 June 2017), 2017.

[25] Luka Ploče, http://www.luka-ploce.hr/hr/o-luci/razvoj-i-investicije/terminal-rasutihtereta/, (30 June 2017), 2017.

[26] C.A. Masoli, L. Petronio, E. Gordini, M. Deponte, D. Cotterle, R. Romeo, F. Meneghini, Marine ecophysical and geological investigations in support to the construction of new harbour infrastructures: The Triestne marine terminal extension, GNGTS 2015, Sessione 3.2, 2015.

[27] Ministry of the Sea, Transport and Infrastructure http://www.mppi.hr/default.aspx?id=9732, (last access: 30 June 2017), 2017.

(MPPI), 
[28] B. Nadilo, Terminal rasutih tereta u luci Ploče - međunarodna suradnja na projektu, Građevinar, Vol. 66, No. 10, pp. 953-964, available at: http://www.casopisgradjevinar.hr/assets/Uploads/JCE 66_2014 10 7 Gradili\%C5\%A1te.pdf, (last access: 30 June 2017), 2014.

[29] NOAA, Hydrographic Manual, $4^{\text {th }}$ edition, National Oceanic and Atmospheric Administration, US Department of Commerce, Rockwille 1976.

[30] R.A. Pickrill, B.J. Todd, The multiple roles of acoustic mapping in integrated ocean management, Canadian Atlantic continental margin, Ocean and Coastal Management, Vol. 46, No. 6, pp. 601-614, 2003. https://doi.org/10.1016/S0964-5691(03)00037-1

[31] W.H. Press, S.A. Teukolsky, W.T. Vetterling, B.P.P. Flannery, Numerical Recipes in C, The Art of Scientific Computing, Cambridge University Press, New York, 1988.

https://doi.org/10.1016/S0003-2670(00)82860-3

[32] P. Ramsay, W. Miller, Marine GEOSOLUTIONS, Multibeam and sub-bottom profiling surveys for major port expansions, PositionIT, pp. 29-33, available at: http://www.ee.co.za/wpcontent/uploads/legacy/PositionIT\%202009/PositionIT\%202010/multibeam.pdf, llast access: 30 July 2017), 2010.

[33] RijekaProjekt, Studija procjene utjecaja na okoliš ciljanog sadržaja - Kontejnerski terminal Ploče u luci Ploče, Rijeka, 2004.

[34] J.A. Sciortino, Fishing harbour planning, construction and management, Food and Agriculture Organization of the United Nations, Rome, 2010.

[35] W.H. Smith, D.T. Sandwell, Conventional bathymetry, bathymetry from space, and geodetic altimetry, Oceanography, Vol. 17, No. 1, pp. 8-23, available at: http://faculty.une.edu/cas/szeeman/oce/articles/bathymetry measurement.pdf, (last access: 30 August 2017), 2004. https://doi.org/10.5670/oceanog.2004.63

[36] A. Šiljeg, Digital terrain model in the analysis of geomorphometrical parameters-the example of Nature park Lake Vrana, Doctoral dissertation, The Faculty of Science, Department of Geography, University of Zagreb, available at: https://bib.irb.hr/datoteka/635259.DMR u analizi geomorfometrijskih parametara PP Vransko jezero.pdf, (last access; 30 July 2017), 2013.

[37] C. Wienberg, J. Dannenberg, D. Hebbeln, The fate of dumped sediments monitored by a high-resolution multibeam echo-sounder system, Weser Estuary, German Bight, GeoMarine Letters, Vol 24, No. 1, pp. 22-31, 2004.

https://doi.org/10.1007/s00367-003-0155-9 